\title{
MIGRACE V SOCIÁLNÍM UČENÍ CÍRKVE
}

\author{
PETR ŠTICA
}

Sociálně citlivý postoj vůči cizincům a jejich situaci patřil po celé dějiny církve k důležitým oblastem sociálního zájmu křestanských církví. Ctnost pohostinnosti a pomoc lidem na cestách se staly součástí étosu a charitativní činnosti prvotních církevních obcí, jak o tom svědčí různé biblické i nebiblické prameny. Ve světle starozákonních i novozákonních textů lze přijetí cizince a pomoc lidem na cestách chápat jako důležitou součást křestanského étosu - jako jeden ze znaků autentického křestanského života a jeden z projevů služby lásky jak ve formě individuální pomoci, tak prostřednictvím pomoci organizované ze strany církevních obcí. ${ }^{1}$ Křestané a teologové tedy mohou, pokud jde o eticky zaměřené zkoumání migrace, navázat na dlouhou biblickou a církevní tradici, kterou vyznačuje pozornost vůči lidem na okraji společnosti, jejichž hlas ze strany většinové společnosti může být přehlížen. Není tedy divu, že otázka migrace, pozornost vůči migrantům a lidem na cestách hraje významnou roli rovněž v sociálním učení církve.

V následujících odstavcích bych rád představil základní sociálně-eticky orientované texty církevního magistéria a $\mathrm{v}$ historickém přehledu ukázal základní vývojové linie dokumentů katolické církve ve vztahu $\mathrm{k}$ problematice migrace. $\mathrm{Z}$ pochopitelných důvodů bude naše pozornost téměř výhradně soustředěna na celocírkevní dokumenty - sociální encykliky, texty papežů, koncilů a vybraných vatikánských úřadů. Z řady pozoruhodných dokumentů místních církví, které tvoří neopomenutelnou součást sociálního učení církve - a které by

$\overline{1}$ Podrobněji k biblickému étosu přijímání cizinců srov. ŠTICA, Petr. Cizinec v tvých branách. Biblické podnéty pro etickou reflexi migrace. Praha: Karolinum, 2010. 
bylo pro komplexní obraz problematiky žádoucí do článku rovněž recipovat, což však bohužel z důvodu omezeného rozsahu není možné -, uvedu v závěru pouze jeden, který mezi nimi podle mého názoru zaujímá významné místo. Text je rozdělen do dvou částí: v první části budou představeny a komentovány základní myšlenkové linie a texty k danému tématu v chronologicko-tematické perspektivě, ve druhé části bude pozornost věnována odůvodnění postoje k migrace, s nímž se ve vybraných dokumentech můžeme setkat.

\section{Migrace v sociálním učení církve - historický nástin}

V přehledu základních myšlenkových linií sociálního učení církve o migraci lze vypozorovat určité převažující charakteristiky. V různých obdobích se církevní texty zaměřovaly na určité oblasti a témata, která lze více méně klasifikovat do následujících čtyř skupin. Nelze však pochopitelně tvrdit, že by tato témata a argumentace, které v dané době převažují nebo se nově objevují, nebyly v následujících letech v dokumentech vůbec přítomny. Je však pozoruhodné, jak se tato témata a argumentační linie proměňovaly a vyvíjely. Tato dynamika odráží nejen dynamiku ve vývoji migrace a migračních proudů v daných obdobích a historických okolnostech, nýbrž je namnoze odrazem dějinného vývoje sociálního učení církve jako celku. V postoji k migraci se rovněž odrážejí témata a způsoby argumentace, které jsou charakteristické pro sociální učení jednotlivých papežů. ${ }^{2}$

\subsection{Péče o migranty a lidi na cestách jako pastorační a sociální výzva pro místní církve (od encykliky Rerum novarum až po motu proprio Exsul familia)}

Cizincům a imigrantům se zvýšené pozornosti ze strany církevních představitelů dostává ve druhé polovině 19. století v souvislosti s narůstajícím počtem imigrantů (především v Evropě). Církve a církevní obce a organizace se během 19. století s novou naléhavostí zapojují do sociálních aktivit a služeb sociální pomoci, včetně péče o imigranty.

\footnotetext{
2 V této části navazuji na jednu kapitolu ze své monografie (srov. ŠTICA, Petr. Migrace a státni suverenita. Oprávnèni a hranice pristèhovalecké politiky z pohledu křestanské sociálni etiky. Červený Kostelec: Pavel Mervart, 2010, s. 261-268). V rámci tohoto upraveného, významně rozširreného a v tomto smyslu nového zpracování svou reflexi přepracovávám a novým způsobem systematizuji. Zároveň zde recipuji aktuální, nedávno publikované zahraniční studie k uvedenému tématu.
} 
Rovněž v odborné teologické obci se po dlouhé době ${ }^{3}$ objevuje opět několik prací, které se tímto tématem zabývají, především ve vztahu $k$ pastoraci těchto skupin. Podobně se i papežové v různých proslovech a kázáních věnují problematice migrantů. Církevní dokumenty a teologické spisy se však této „nové sociální otázce“ věnují prakticky výhradně „,Z aspektu sociální péče, charitativní pomoci a duchovního doprovázení emigrantů““. Sociálně-etická reflexe migrace, respektive úvahy o spravedlivém zacházení s fenoménem migrace (imigrace i emigrace) a s přistěhovalci či emigranty obecně v podstatě stojí mimo pozornost teologů a církevních představitelů.

Sociální a pastorační péče o přistěhovalce však zaujímá především od prvních desetiletí 20. století velmi důležitou roli. Prvním významným dokumentem, který se zabývá výhradně touto problematikou, je motu proprio papeže Pia X. Iam pridem, které bylo publikováno 19. března 1914. V něm papež mimo jiné vyzývá ke stanovení „dne migrace“, zřízení papežského kolegia pro otázky spojené s italskými vystěhovalci a ustanovení diecézní komise pro migraci. Papež zde navazuje na své bohaté osobní zkušenosti s pastorací migrantů z doby svého kněžského a biskupského působení. V motu proprio navazuje ostatně rovněž na své předchozí kratší spisy, především dopisy biskupům, v nichž ordináře vyzývá k tomu, aby přistěhovalcům a jejich duchovnímu doprovázení věnovali zvláštní pozornost. ${ }^{5}$

Požadavek zvláštní pozornosti, kterou je třeba věnovat pastoraci migrantů a sociální pomoci ze strany charitativních organizací, se objevuje i v proslovech a krátkých dokumentech papežů z následujících let ${ }^{6}$ i v dekretech patřičných vatikánských kongregací. ${ }^{7}$ Zvýšenou

3 První sociálně-etickou a zároveň teologickou reflexi nacházíme v období španělské „druhé scholastiky“. Srov. RETHMANN, Albert-Peter. Počátky etiky migrace. Francisco de Viktoria OP a Salamanská škola. Salve: Revue pro teologii a duchovní život 2004 , č. 1 , s. $70-76$.

4 GIL, Francisco Prieto. Die Aus- und Einwanderungsfreiheit als Menschenrecht: zur Geschichte des Rechts und zu seiner christlichen Begründung heute. Regensburg: Pustet, 1976, s. 146.

5 Srov. KÖPPEL, Urs. Die Kirche vor der Herausforderung der Migration. Internationale Katholische Zeitschrift Communio 1999, č. 3, s. 198-206, zde s. 199.

6 Srov. KRIENKE, Markus. Migration als Ernstfall christlicher Universalität. Sozialethische Erwägungen zu einer pastoralen Herausforderung. Trierer Theologische Zeitschrift 2008, č. 3, s. 253-269, zde s. 258.

7 Jde o dekrety Konzistorní kongregace Ethnografica studia z roku 1914 a Magni semper z roku 1918. První dokument v návaznosti na motu proprio Iam pridem zdůraznil odpovědnost místních církví za pomoc a pastoraci migrantů a doporučoval zvláštní př́pravu místního kléru, který se pastoraci mezi migranty má věnovat. Druhý dekret 
pozornost vůči migraci lze zaznamenat po druhé světové válce, kdy dynamika migračních proudů a množství migrantů opět významně vzrůstá. Migrace a pastorační péče o přistěhovalce se stávají důležitým tématem papeže Pia XII, který do diskuze o migraci vnáší nové aspekty, o nichž bude řeč dále.

Vrchol této tematické linie představuje apoštolská konstituce Pia XII. Exsul familia z 1. srpna 1952. Jde o první dokument, který - ačkoli je výrazně dobově ovlivněn a vychází ze situace italských emigrantů - usiluje o formulování obecných linií pro pastoraci migrantů. ${ }^{8}$ Zdůrazȟuje mimo jiné zvláštní odpovědnost biskupů za pastorační péči o migranty a předkládá řadu normativních pastoračních podnětů. Tato konstituce je považována za první církevní dokument, který systematicky vymezuje pastoraci migrantů z historického a kanonického hledis$\mathrm{ka}^{9}$ a téma migrace pojednává komplexně, včetně teologické reflexe. ${ }^{10}$

Toto motu proprio představuje spolu se založením Mezinárodní komise katolických biskupských konferencí pro práci s migranty a uprchlíky (1951) určitý symbolický vrchol první etapy církevních dokumentů zabývajících se migrací. ${ }^{11}$ Znamená zároveň - stejně jako pontifikát Pia XII. - určitý zlom v otázkách migrace, které je v rámci celocírkevních dokumentů od té doby věnována významná pozornost.

\subsection{První sociálnè-etická reflexe migrace v církevních dokumentech - různá pojetí práva na migraci (pontifikát Pia XII. až pontifikát Pavla VI.)}

Zatímco církevní dokumenty vyznačoval až do prvních let po druhé světové válce především zájem o charitativní, sociální a pastorační aspekt migrace - a je třeba dodat, že intenzivní zájem o pastoraci

vymezoval kompetence v oblasti přípravy kléru a regulaci této specializované pastorace. Tato problematika byla svěřena Posvátné konzistorní kongregaci.

8 Srov. KÖPPEL, Urs. Die Kirche vor der Herausforderung der Migration, s. 199-200.

9 Proto jej explicitně uvádí rovněž nový dokument Papežské rady pro pastoraci migrantů a lidí na cestách Erga migrantes caritas Christi. Ten charakterizuje motu proprio jako „magnu chartu církevního myšlení o migraci.“ - PAPEŽSKÁ RADA PRO PASTORACI MIGRANTU゚ A LIDÍNA CESTÁCH: Ergamigrantes caritas Christi(2004), Praha 2006, čl.20.

10 Srov. RAJENDRA, Tisha M. Migration in der katholischen Soziallehre. Concilium. Internationale Zeitschrift für Theologie 2011, č. 3, s. 247-256, zde s. 248.

11 Mezinárodní komise, známá rovněž jako Mezinárodní katolická migrační komise, vznikla z podnětu amerických, italských a německých laiků stejně jako vatikánského Státního sekretariátu, msgre. Montiniho (pozdějšího papeže Pavla VI.) a kardinála Josefa Fringse. - Srov. LOUGHRY, Maryanne. Wer ist noch mit im Boot - oder im Lastwagen? Gemischte Ströme: Menschenhandel und Zwangsmigration. Concilium. Internationale Zeitschrift für Theologie 2011, č. 3, s. 237-246, zde s. 243. 
migrantů a lidí na cestách církevní dokumenty již neopustí -, objevují se v následujících církevních dokumentech první skutečně sociálně-etické reflexe fenoménu migrace jako celku, tedy reflexe migrace z pohledu spravedlnosti. ${ }^{12}$ Takovou perspektivu v otázkách migrace používá poprvé papež Pius XII. v rámci svých proslovů a krátkých spisů. Je třeba podotknout, že migrace v jeho sociálně orientovaných textech nepředstavuje marginální téma, nýbrž naopak. Chronologicky první zmínku nalezneme v jeho Svatodušním poselství z roku 1941, vydaného u příležitosti 50. výročí encykliky Rerum novarum. Papež zde hovoří o pozitivním náhledu na migraci, která má být chápána jako příležitost pro realizaci dobra všech zúčastněných a tedy jako příspěvek ke společnému (obecnému) dobru:

Rodiny [prostřednictvím migrace] získávají nový domov ve vlastním slova smyslu; přelidněným státům je ulehčováno a samy si díky vystěhování vytvářejí nové přátele $\mathbf{v}$ cizích zemích. Přijímající státy získávají občany schopné práce. Oba aktéři - státy, které uvolňují část svého četného obyvatelstva, i státy přijímající - takto a jen takto přispějí k nárůstu lidského štěstí a kultury humanity. ${ }^{13}$

Migrace je interpretována jako znamení času, které s sebou přináší šanci pro integrální rozvoj jednotlivce i společnosti. Velmi napínavou a nově položenou otázku, kterou lze v následujících spisech a proslovech Pia XII. nalézt, je pak reflexe práva na migraci - tedy práva na vystěhování a přistěhování. Tato otázka, která je po druhé světové válce nově diskutována rovněž v souvislosti s materiálním rozsahem Všeobecné deklarace lidských práv (1948), představuje v dokumentech Pia XII. a jeho nástupce Jana XXIII. důležité téma.

12 Jedinou výjimku v předchozích sociálních encyklikách, kde je migrace reflektována nikoli z pastoračního či charitativního aspektu, nýbrž jako sociální skutečnost, představuje krátká zmínka o podstatě migrace v první sociální encyklice Rerum Novarum. Lev XIII. tu upozorňuje na zásadní věc - imigrace většinou není záležitosti touhy po dobrodružství, nýbrž je reakcí na situaci nouze, či dokonce sociálně-ekonomickou nutností. - LEV XIII. Rerum novarum, čl. 35. Citáty ze sociálních encyklik jsou - není-li uvedeno jinak - čerpány z českého vydání: Sociální encykliky (1891-1991), Praha: Zvon, 1996.

13 PIUS XII. Svatodušní poselství u př́ležitosti 50. výročí encykliky Rerum novarum. Acta Apostolicae Sedis (dále jen AAS) (1941), s. 247. Citováno podle GIL, Francisco Prieto. Die Aus- und Einwanderungsfreiheit, s. 161. 
Chronologicky první papežský dokument, v němž je zmínka o právu na vystěhování a přistěhování, představuje dopis arcibiskupovi v Cincinnati z roku 1948. V něm Pius XII. mj. píše:

Přirozené právo samo neméně než ohled vůči [jednotlivému] člověku zavazuje k tomu, aby bylo vystěhování umožňováno. Stvořitel všech věcí totiž stvořil všechna dobra k dobru člověka. Právo státu na své výsostné území, které má být také vždy bráno v potaz, nesmí být proto zneužito k tomu, aby zabraňovalo vstupu na území státu bez spravedlivého a závažného důvodu, pokud se jedná o cizince v nouzi, kteří nepředstavují žádné nebezpečí pro veřejné dobro. ${ }^{14}$

Právo na emigraci lze tedy podle Pia XII. interpretovat jako základní lidské právo, které je $\mathrm{v}$ souladu s přirozeným právem a kterému nemá být bráněno. Poukazuje dále na odůvodněnost regulace migrace ze strany jednotlivých států. Ta se má však řídit podle etických kritérií - s ohledem na situaci imigrantů a na obecné dobro.

Ve vánočním poselství z roku 1952 pak papež upozorňuje na to, že regulace migrace nesmí být ani zneužívána ani koncipována bez ohledu na přicházející migranty coby lidské osoby, usilující o důstojnější život, stejně jako na přijímající společnost, která je schopna v přítomnosti a budoucnosti uživit občany dané země včetně přicházejících migrantů. Migrace má být regulována spravedlivě tak, aby „přirozenému právu na vystěhování a přistěhování nebylo bráněno“, ${ }^{15}$ respektive aby toto právo nebylo zraňováno. ${ }^{16}$

Pius XII. tedy interpretuje jednoznačně - podobně jako Všeobecná deklarace lidských práv - právo na vystěhování jako lidské právo. Ohraničeným způsobem pak interpretuje coby lidské právo rovněž právo na přistěhování u „potřebných cizinců“, kteří se nacházejí v situaci nouze a kteří hledají v nové zemi šanci pro rozvinutí lepšího života a naplnění lidských práv. Na tuto argumentaci navazuje nástupce Pia XII., Jan XXIII., který této problematice věnuje pozornost v sociální encyklice Pacem in terris (1963). V ní recipoval do sociálního učení církve novodobý koncept lidských práv coby základ církevního sociálního učení.

14 AAS (1949), 69-70. Citováno podle GIL, Francisco Prieto. Die Aus- und Einwanderungsfreiheit, s. 156.

15 PIUS XII. Vánoční poselství z roku 1952. AAS (1953), 41.

16 Srov. GIL, Francisco Prieto. Die Aus- und Einwanderungsfreiheit, s. 159. 
V úvodu encykliky (čl. 8-45) předložil Jan XXIII. vlastní seznam lidských práv a povinností. V jeho výčtu se - na rozdíl od Všeobecné deklarace lidských práv, na niž Jan XXIII. kreativně reaguje - objevuje vedle velmi jasného vyjádření práva na vystěhování rovněž právo na přistěhování:

Každý člověk má mít plné právo na svobodu pobytu a pohybu uvnitř státu, jehož je občanem; a pokud k tomu vede oprávněný důvod, má také právo přestěhovat se do jiného státu a usadit se v něm. Tím, že někdo je občanem jiného státu, nepřestává být členem velké lidské rodiny, občanem světového společenství všech lidí. ${ }^{17}$

Podobně jako jeho předchůdce tedy právo na přistěhování chápe $\mathrm{s}$ určitou hranicí - $\mathrm{k}$ přijetí cizince má vést oprávněný důvod (causa iusta). Co myslí Jan XXIII. spojením oprávněný důvod, dokresluje později na jiném místě téže encykliky:

Mezi právy lidské svobody zasluhuje uznání také to, že každý může odejít do takového státu, v němž, jak doufá, se bude moci lépe postarat o sebe i o svou rodinu. Je proto povinností státníků přijímat přistěhovalce a, pokud to dovoluje blaho jejich společenství, být vstřícní vůči úmyslu těch, kteří se snad chtějí začlenit do nové společnosti. ${ }^{18}$

Tento požadavek přijetí osob, které žijí v hospodářsky a sociálně horších podmínkách než lidé v přijímající společnosti a které se v nové společnosti chtějí usadit, klade otázku, zda a za jakých podmínek mohou ekonomicky silnější státy upírat příchod a usazení občanům z chudších států či přicházejících z hospodářsky a sociálně méně rozvinutých

17 JAN XXIII. Pacem in terris, čl. 25. Papež se zde odvolává a navazuje na již uvedené vánoční poselství svého předchůdce z roku 1952. Latinský originál zní: „Tum etiam homini cuilibet iure integrum esse debet in civitatis suae finibus vel tenere vel mutare locum; quin etiam, si iustae id suadeant causae, eidem liceat necesse est, alias civitates petere in iisque domicilium suum collocare. Neque ex eo quod quis certae cuiusdam reipublicae est civis, is ullo modo vetatur esse membrum humanae familiae, neque civis universalis illius societatis et coniunctionis omnium hominum communis.“ (Zdůraznění P. Š.)

18 Tamtéž, čl. 106, s. 206. Latinský originál zní: „Iamvero inter humanae personae iura illud etiam recensendum est, licere cuique se in eam nationem conferre, ubi aptius se posse speret sibi atque suis necessariis prospicere. Quare rei publicae moderatorum officium est alienos venientes excipere, et, quantum suae communitatis sinit non fucatum bonum, eorum proposito favere, qui forte novae societati sese velint aggregare.“ 
a uspokojivých podmínek. V perspektivě papeže Jana XXIII. je společenství - pokud to nepřesahuje jeho možnosti - zavázáno k přijímání chudých cizinců, kteří přicházejí v míru a chtějí se usadit. Předpokládá se tedy otevřenost a solidární postoj ze strany přijímajících států vůči politickým uprchlíkům, ale i ekonomickým imigrantům.

Jan XXIII. jde ve své úvaze a argumentaci dále než Pius XII. a hovoří o tom, že právo na přistěhování se týká nejenom těch, kteří se nacházejí ve stavu nouze, nýbrž všech, kteří k vystěhování mají oprávněný, doslova spravedlivý důvod. Můžeme tedy říci, že na rozdíl od Pia XII., který uznává právo na imigraci pro lidi v nouzi, vyjadřuje se Jan XXIII. pozitivně k právu na imigraci obecně. Toto právo však nechápe bezhraničně, ale podmiňuje ho špatnou hospodářskou či politickou situací v zemi původu imigrantů na jedné straně a obecným dobrem přijímající země na straně druhé. ${ }^{19}$

Pastorální konstituce Druhého vatikánského koncilu Gaudium et spes se tématem migrace zabývá ve dvou článcích. V návaznosti na předchozí sociální encykliky však jasně zdůrazňuje, že osobní právo na migraci - aniž by jej konstituce $\mathbf{v}$ uvedeném článku jakkoli specifikovala - má zůstat nedotčeno. ${ }^{20}$

Dále zdůrazňuje, že regulace migrace cizinců do společnosti má být určována idejí lidských práv a má být v souladu s lidskou důstojností. Klíčovou roli zde hrají spravedlivé podmínky v různých oblastech společenského života a úsilí o sociální integraci přistěhovalců:

Právo a spravedlnost rovněž vyžadují, aby pohyb pracovníků, který nutně provází rozvoj hospodářství, byl řízen tak, aby život jednotlivců a jejich rodin nebyl vystaven nejistotě a ohrožení. Vůči dělníkům, kteří pocházejí

19 Srov. RETHMANN, Albert-Peter. Asyl und Migration. Ethik für eine neue Politik in Deutschland. Münster: Lit Verl., 1996, s. 269-270; Francisco Prieto Gil poznamenává, že hranici pro přijímání cizinců představuje především idea obecného dobra. Ta se však týká jak přijímajících států, tak států, z nichž migranti odcházejí (a do hry tak vstupuje např. problematika odlivu flexibilních a kvalifikovaných pracovních sil z hospodářsky méně rozvinutých zemí). Srov. GIL, Francisco Prieto. Die Aus- und Einwanderungsfreiheit, s. 158.

20 Srov. Gaudium et spes, čl. 65. Český překlad zde podobně jako překlad německý překládá „migraci“ nepřesně a mluví místo o „právu na migraci“, jak stojí v originálním textu, o „právu na vystěhování“. Anglický a francouzský překlad zde důsledně překládá migraci tak, jak to stojí rovněž v latinském originále. Ten zní: „Praesertim in regionibus oeconomice minus progressis, ubi omnes opes urgenter adhibendae sunt, bonum commune graviter in discrimen vocant qui opes suas infructuosas retinent vel - salvo iure personali migrationis - communitatem suam subsidiis sive materialibus sive spiritualibus privant quibus illa eget.“ (Zdůraznění P. Š.). 
z jiného národa nebo jiné země a přispívají svou prací k hospodářskému povznesení obyvatelstva nebo území, je třeba se pečlivě vyhýbat jakékoli diskriminaci v platových nebo pracovních podmínkách. Kromě toho všichni - a především veřejná moc - mají s nimi jednat ne jako s pouhými výrobními prostředky, ale jako s osobami, a mají jim pomáhat, aby si mohli k sobě vzít rodinu a opatřit si slušné ubytování; mají se starat o to, aby se včlenili do společenského života národa nebo země, které je přijaly. ${ }^{21}$

Pastorální konstituce tak vedle potřeby integrace cizinců, která je úkolem jak přijímající společnosti, tak přicházejících cizinců, uvádí na scénu mnohovrstevnatou tematiku lidsko-právních aspektů spjatých s migrací, jež budou v církevních dokumentech hrát klíčovou úlohu v následujících letech. Zároveň je v souvislosti s nimi v dokumentu řeč o potřebě předcházet příčinám migrace vytvářením pracovních př́ležitosti v zemích původu a dalšími nástroji pro zmírňování příčin migrace. Je tak správně poukázáno na to, že migrace není samoúčelným nebo náhodným fenoménem, nýbrž komplexním jevem, který je podněcován řadou „push-faktorů“ a „pull-faktorů“ (např. nemožností rozvíjet své osobní šance a uživit sebe a své blízké v místě původu, respektive snadnější možností rozvinutí těchto šancí v přijímající zemi). Migraci podle koncilních textů nelze chápat jako izolovaný fenomén, jehož regulace spočívá výhradně ve státních kontrolách suverénních států, jež určují příchod a usazení cizinců. Jde o globálně-etický problém, který je třeba řešit bojem proti příčinám migrace a uprchlictví a úsilím o integrální rozvoj, který je úkolem jak jednotlivých států (emigračních i imigračních), tak světového společenství. ${ }^{22}$

V šedesátých letech je z relevantních celocírkevních dokumentů třeba dále zmínit dokument Kongregace pro biskupy, pod níž byla od roku 1952 otázka pastorace migrantů zařazena a kde byla k tomuto účelu vytvořena Vyšší rada pro emigranty. Výsledkem dlouhodobé práce kongregace $\mathrm{v}$ této oblasti byl vznik instrukce pro pastorální péči o migranty De pastorali migratorum cura, která byla publikována 22. srpna 1969. ${ }^{23}$ Instrukce formulovala vedle podrobných pastoračních linií

21 Tamtéž, čl. 66.

22 Srov. WISSENSCHAFTLICHE ARBEITSGRUPPE FÜR WELTKIRCHLICHE AUFGABEN DER DEUTSCHEN BISCHOFSKONFERENZ (ed.). Ökonomisch motivierte Migration zwischen nationalen Eigeninteressen und weltweiter Gerechtigkeit. Bonn: Dt. Kommission Justitia et Pax, 2005, s. 37.

23 Srov. SACRA CONGREGATIO PRO EPISCOPIS, De pastorali migratorum cura. AAS (1969), s. 614-643. 
diferencované směrnice pro pastoraci migrantů, které zahrnovaly mj. vytvoření specifických pastoračních struktur pro imigranty. ${ }^{24}$ Promulgaci tohoto dokumentu předcházelo vydání motu propria Pavla VI. se stejným názvem (15. srpna 1969). ${ }^{25}$

Instrukce se v úvodních pasážích zabývala rovněž sociálně-etickou reflexí migrace. V ní potvrzuje učení předcházejících papežů o právu na emigraci a odůvodněném právu na imigraci. Jako odůvodněné právo na imigraci je interpretováno úsilí o lepší a důstojný život. ${ }^{26}$ Co se týče regulace migrace, uznává její oprávnění ze strany přijímajících států, nicméně pouze tehdy, pokud by prostřednictvím přistěhování vznikalo společnosti vážné poškození obecného dobra. ${ }^{27}$

Od pontifikátu Pia XII. do konce šedesátých let v celocírkevních dokumentech převládá diskurz o právu na migraci, diskurz, v jehož rámci lze vypozorovat určitou variabilitu. Zatímco Pius XII. mluví o právu na emigraci a imigraci jako o lidském právu, přičemž právo na imigraci je podmíněné (obecným dobrem, stavem nouze přistěhovalce), tendují texty Jana XXIII. a pastorální konstituce Gaudium et spes k ještě „otevřenějšímu pojetí“ práva na imigraci. V každém případě je však v řadě celocírkevních textů této doby patrné, že chápou migraci především pozitivním způsobem a zdůrazňují pozitivní dopady migrace na jednotlivé přistěhovalce stejně jako na hospodářství a rozvoj přijímajících států. ${ }^{28}$

24 Srov. KRIENKE, Markus. Migration als Ernstfall christlicher Universalität, 255. Ke kritice těchto pastoračních zásad srov. LEUNINGER, Herbert. Eine Nebenkirche oder die Einheit in der Vielfalt? Die Gemeinden von Katholiken anderer Muttersprache in der Bundesrepublik Deutschland. In Klaus Barwig, Dietmar Mieth (ed.), Migration und Menschenwürde - Fakten, Analysen und ethische Kriterien. Mainz: Matthias Grünewald Verl., 1987, s. 158-177.

25 Srov. AAS (1969), s. 601-603.

26 Relevantní pasáž je uvedena nadpisem „Právo na migraci (Ius migrandi)“. Zahrnuje následující myšlenky: „Nativum asseritur hominis ius materialibus ac spiritualibus bonis utendi, quibus propriam perfectionem plenius atque expeditius consequatur. Ubi vero civitas, quae rerum inopia et magna civium frequentia laboret, nequeat incolis talium bonorum usum suppeditare, aut condiciones ponat humanam dignitatem laedentes, migrandi iure homo perfruitur et novam domum in exteris terris seliquendi vitaeque condiciones homine dignas quarendi.“ Tamtéž, s. 617.

27 „Publicae Auctoritates ius humanae personae immerito negent si vel emigrationi vel immigrationi obstent aut impedimenta adducant, praeterquam si gravi boni communis ratione ex veritate considerata id requiratur." Tamtéž. (Zdůraznění P. Š.) Nelze si nepovšimnout, že se text odvolává na učení encykliky Pacem in terris a na relevantní pasáže z pastorální konstituce Gaudium et spes (čl. 65-66).

28 Srov. např. JAN XXIII. Proslov ke členům Vyšší rady pro imigraci (20. 10. 1961). In AAS (1961), s. 717 či Proslov u příležitosti desátého výročí vydání motu propria Exsul familia (5. 8. 1962), In AAS (1962), s. 579; srov. PAVEL VI. Rozhlasové poselství ke Dni 
Pavel VI. přispívá do reflexe o migraci a uvádí v závislosti na doporučení instrukce De pastorali migratorum cura $^{29}$ otázku nového práva v rámci diskurzu o právu na migraci - tím je právo na přistěhování rodin. Toto právo na sloučení rodin se odráží rovněž v diskurzu o různých lidsko-právních aspektech migrace, které ve vybraných textech stručně předznamenali i jeho předchůdci. ${ }^{30}$ Právě tyto aspekty se dostanou do popředí $\mathrm{v}$ rámci celocírkevních textů o migraci $\mathrm{v}$ následujícím období.

\subsection{Lidsko-právní aspekty migrace}

Nejprve je třeba podotknout, že zájem o otázky migrace a pastorace migrantů za pontifikátu Pavla VI. neutichá, ba naopak. Dynamika migrace s sebou přináší nové otázky. Není tedy divu, že se nárůst zájmu o tyto otázky vedle uvedené instrukce projevil rovněž na institucionální rovině. Z podnětu Pavla VI. byla roku 1970 na Kongregaci pro biskupy zř́zena Papežská komise pro migranty a turisty. Ta byla později na základě apoštolské konstituce Jana Pavla II. Pastor bonus roku 1988 vyňata z jurisdikce Kongregace pro biskupy a od té doby představuje pod názvem Papežská rada pro pastoraci migrantů a lidí na cestách (Pontifical Council for the Pastoral Care of Migrants and Itinerant People) samostatný orgán v rámci římské kurie.

Pavel VI. - přestože ve svých úvahách důsledně navazoval na úvahy svých předchůdců i na pastorální konstituci Druhého vatikánského koncilu - se ve svých textech o migraci zaměřil postupně především na lidsko-právní aspekty zacházení s imigranty v přijímajících zemích a na jejich sociální integraci. Vyjadřoval se k otázce přistěhování především v souvislosti s pracovní migrací a mj. nabádal zaměstnavatele, stát a patřičné organizace k tomu, aby dbali na důstojné a spravedlivé pracovníky podmínky zahraničních pracovníků, aby podporovali jejich integraci a nezabraňovali přistěhování rodin. ${ }^{31}$ Bernhard Eder

emigrantů (24. 11. 1963) aj. K těmto textům srov. GIL, Francisco Prieto, Die Aus- und Einwanderungsfreiheit, s. 161.

29 Instrukce uvádí, že právo na migraci nelze chápat pouze jako právo jednotlivce, nýbrž rovněž jako právo rodiny: „Neque tantum singulis personis, sed familiis universis hoc plenum pertinet ius." AAS (1969), s. 617.

30 Srov. např. JAN XXIII. Proslov u př́ležitosti desátého výročí vydání motu propria Exsul familia. AAS (1962), s. 579.

31 Srov. PAVEL VI. Octogesima adveniens, čl. 17. V této souvislosti papež zmiňuje povinnost „,v̌̌ech, a zvláště křestanů, aby energicky pracovali na nastolení bratrství národů“; srov. rovněž TÝŽ, Populorum progressio, čl. 69 . 
hovoří po právu o tom, že v rámci spravedlivého zacházení s migranty hraje pro Pavla VI. hlavní úlohu kontributivní spravedlnost, tedy důraz na začlenění migrantů do společnosti v rámci oblasti politické (usnadnění získání občanství a politických práv), hospodářské (spravedlivé podmínky při vstupu na pracovní trh a v rámci zaměstnávání - spravedlivá mzda, korektní pracovně-právní vztahy, zabránění diskriminaci a vykořistování zahraničních pracovníků) a společensko-privátní (slučování rodin, kterému nemá být bráněno). ${ }^{32}$

Lidsko-právní aspekty migrace hrají klíčovou roli rovněž v dokumentech Jana Pavla II. Zvláštní pozornost je tomuto tématu věnována v článku 23 sociální encykliky tohoto papeže o lidské práci. Jan Pavel II. se zde vyjadřuje kladně k právu na vystěhování, přestože tím země původu „ztrácí“ podnikavé občany. Tyto ztráty však vyvažují klady pro všechny zúčastněné aktéry - především pak pro jednotlivé přistěhovalce a jejich rodiny, ale i pro přijímající země. Největší pozornost pak papež věnuje spravedlivému zákonodárství v přijímající zemi, které by mělo bránit tomu, aby imigranti v dané zemi byli diskriminováni či finančně a sociálně vykořistováni. ${ }^{33}$

Zvláštní platformou pro uvedené úvahy se stávají Světové dny uprchlíků a migrantů, při jejichž příležitosti papežové každoročně od roku 1978 pronášejí zamyšlení nad aktuálními tématy spojenými s migrací a uprchlictvím. I zde hraje lidsko-právní problematika důležitou úlohu. Chtěl bych v množství témat z těchto projevů a publikovaných reflexí papežů, které zde z pochopitelných důvodů nelze uvést $\mathrm{v}$ jejich úplnosti, poukázat zástupně pouze na jeden příklad. Poselství ke Světovému dni migrantů z roku 1996 se věnuje jednomu z nejpalčivějších aktuálních etických témat migrace - nelegálnímu (či iregulárnímu) přistěhovalectví. V souladu s tradicí ochrany slabých papež mj. poukazuje na to, že „statut nelegálního přistěhovalectví neopravňuje ke snižování důstojnosti migranta, který je nositelem nezcizitelných práv, jež nemohou být porušována ani ignorována“ (čl. 3). Proto má být pozornost věnována nejen předcházení ilegálnímu přistěhovalectví, nýbrž rovněž boji s vykořistováním iregulárních přistěhovalců a se zločinnými iniciativami různých aktérů $\mathrm{v}$ přijímajících zemích, které na tomto nečestném obchodu s iregulárními migranty vydělávají. Dokument přitom

32 Srov. EDER, Bernhard. Katholische Soziallehre und Migration: zum Spannugsfeld von universaler Ausrichtung und nationalstaatlicher Orientierung. Theologisch-praktische Quartalschrift 2000, č. 4, s. 396-404, zde s. 399.

33 Srov. JAN PAVEL II. Laborem excercens, čl. 23. 
zmiňuje řadu konkrétních podnětů pro jednání od materiální pomoci až po poradenství a administrativní pomoc. Podobně lze lidsko-právní aspekty migrace vypozorovat v dalších poselstvích ke Světovému dni migrantů, např. v souvislosti s migrací žen (Poselství 1994-1995) či s požadavkem přiměřené integrace.

Podle řady autorů hraje lidsko-právní problematika v rámci reflexe migrace církevních dokumentů zvláště v posledních letech zásadní roli. ${ }^{34}$ Silvano Tomasi to dokumentuje mj. pozitivním přijetím Úmluvy o ochraně práv všech migrujících pracovníků a členů jejich rodin ze strany Svatého stolce. ${ }^{35}$ Valné shromáždění OSN přijalo dokument po dlouhodobé př́pravné práci v roce 1990. Úmluva nicméně vstoupila v platnost až po ratifikaci dostatečného množství členů, k níž došlo 1. července 2003. Dokument usiluje o zachování lidských práv migrantů a ukotvení standardů, které vyplývají z dosavadních právních instrumentů. Mezi právy migrantů, na něž je třeba zvláště brát zřetel, zmiňuje např. právo na život, zákaz práce v nelidských podmínkách, zákaz fyzického a sexuálního zneužívání a ponižujícího zacházení, zákaz otroctví a nucené práce, právo přístupu k informacím o vlastních právech, právo na rovnost před zákonem a právo rovného přístupu ke vzdělání a ke zdravotní péči. ${ }^{36}$ Jan Pavel II. se vzápětí po jejím schválení k této konvenci vyjádřil pozitivně, bezpochyby rovněž proto, že její lidsko-právní apely byly namnoze totožné s požadavky magistéria. Podobně se k uvedené konvenci vyjádřil později i Benedikt XVI.37

Nikoli neprávem lze charakterizovat tuto epochu církevních dokumentů ve vztahu k otázkám migrace především koncentrací na lidskoprávní problematiku. Nutno dodat, že advokatorní funkce křestanské církve jako zastánce chudých a marginalizovaných a senzibilizátorky veřejné debaty představuje leitmotiv novodobého sociálního učení církve v otázkách migrace.

34 Srov. HORNSBY-SMITH, Michael P. An Introduction to Catholic Social Thought, Cambridge: Cambridge Univ. Press 2006, s.137

35 Srov. TOMASI, Silvano M. Migration und Katholizismus im globalen Kontext. Concilium. Internationale Zeitschrift für Theologie 2008,č. 5, s. 520-537, zde s. 527-528.

36 Srov. LINHARTOVÁ, Karolína. Úmluva o ochraně práv všech migrujících pracovníků a členů jejich rodin. In http://aa.ecn.cz/img_upload/224c0704b7b7746e8a07d f9a8b20c098/KLinhartova_Umluvaoochranepravvsechmigrujicichpracovniku.pdf [1. 9. 2011].

37 Srov. BENEDIKT XVI. Poselství ke světovému dni migrantů a uprchlíků (14. ledna 2007). In Acta České biskupské konference, Praha 2007, s. 15-18, zde s. 16. 


\subsection{Nové aspekty v církevních dokumentech - úsilí o komplexní pohled na migraci a migrace chápaná jako príležitost}

V posledních letech lze v celocírkevních textech vypozorovat některé nové aspekty. ${ }^{38}$ Jde např. o snahu o komplexní nahlížení migrace. Kompendium sociální nauky církve z roku 2004 zdůrazňuje aspekt, který bývá ve veřejných debatách upozad'ován, totiž že stupně blahobytu v rozvinutých zemích bylo dosaženo často rovněž díky nemalému přispění přistěhovalců a že $\mathrm{v}$ souvislosti s demografickou krizí v těchto státech může právě příchod cizinců přispívat k rozvoji společnosti i dnes. Kompendium zmiňuje rovněž regulaci imigrace, kterou lze pokládat za odůvodněnou a která se má řídit podle kritérií spravedlnosti a rovnováhy. ${ }^{39}$ To předpokládá respekt k právům migrantů 40 a solidární postoj, především ze strany ekonomicky silnějších přijímajících států vůči imigrantům z chudých zemí. Adekvátní a eticky odpovědný postoj k imigraci předpokládá jak pomoc přistěhovalcům při jejich integraci do přijímající společnosti, tak požadavek podpory „všeho, co přispívá k nárůstu počtu pracovních př́ležitostí v zemích, odkud tito přistěhovalci přicházejí“.41 Pouze za uvedených podmínek lze hovořit o eticky odpovědné regulaci imigrace.

V poslední sociální encyklice Caritas in veritate reflektuje papež Benedikt XVI. migraci jako jedno z klíčových témat soudobé společnosti. ${ }^{42}$ Při formulování i praxi migrační politiky zdůrazňuje význam mezinárodní spolupráce, především pak význam spolupráce mezi přijímající zeměmi a zeměmi původu. Dále poukazuje na potřebu harmonizace imigračních a azylových politik. ${ }^{43}$

Zvláštní pozornost v rámci našich úvah si zaslouží instrukce Papežské rady pro pastoraci migrantů a lidí na cestách z roku 2004 s názvem

38 Podrobněji k uvedenému tématu srov. rovněž ŠTICA, Petr. Migrace jako znamení času a kairos - Mezinárodní migrace v pohledu vybraných církevních dokumentů. In Krize a kairos - společenské výzvy, Červený Kostelec: Pavel Mervart 2010, s. 76-82.

39 Srov. PAPEŽSKÁ RADA PRO SPRAVEDLNOST A MÍR. Kompendium sociální nauky církve (2004). Kostelní Vydří: Karmelitánské nakladatelství 2008, čl. 298.

40 Zvláště a opakovaně zmiňována jsou opět v návaznosti na předchozí církevní dokumenty ochrana práv pracujících imigrantů a ochrana rodiny (prosazování práva na opětné spojování rodin).

41 Tamtéž, čl. 298.

42 Srov. BENEDIKT XVI. Caritas in veritate. Kostelní Vydří: Karmelitánské nakladatelství 2009, čl. 62.

43 Srov. tamtéž. 
Erga migrantes caritas Christi. ${ }^{44}$ Jejím hlavním cílem je aktualizovat pastoraci migrantů vzhledem k nové situaci. V první části se nicméně dokument věnuje - podobně jako instrukce De pastorali migratorum cura - rovněž sociálně-etické reflexi migrace jako takové.

Instrukce Erga migrantes caritas Christi v úvodní části (čl. 1-11) opakovaně popisuje fenomén migrace jako znameni doby, které může být obohacujici príležitostí pro přijímající společnost i pro přicházející migranty. Zmiňuje přínos migrace pro rozvoj různých států, ale rovněž to, že je migrace „výmluvným znamením sociální, ekonomické a demografické nerovnováhy jak na regionální, tak i na světové úrovni“ (čl. 1). Toto vědomí by mělo stát v pozadí eticky odpovědného zacházení s migrací. Velký prostor je opět věnován reflexi ochrany lidských práv imigrantů (čl. 5-6). Instrukce tak navazuje na myšlenkovou tradici předchozích pojednání o migraci. Zdůrazňuje však na několika místech aspekt, který se v dřívějších textech neobjevoval vůbec či pouze marginálně 45 - opakovaně charakterizuje migraci a multikulturní společnost jako znameni Boži prítomnosti v déjinách a jako krok na cestě k univerzálnímu sjednocení lidstva. Migrace je nahlížena jako jedinečná příležitost pro vzájemné poznávání jednotlivých národů a dialog mezi různými kulturami. ${ }^{46}$ Podobně lze podle instrukce hodnotit rovněž multikulturalitu. Pozitivní nahlížení migrace prohlubuje dokument později, když v ní spatřuje zvláštní příležitost nejen pro budování jednoty lidstva, nýbrž rovněž pro hlásání evangelia. ${ }^{47}$ Dokument Erga migrantes caritas Christi tedy hodnotí skutečnost migrace především jako pozitivní příležitost a popisuje zkušenost s cizinci

44 Srov. PAPEŽSKÁ RADA PRO PASTORACI MIGRANTU゚ A LIDÍ NA CESTÁCH. Erga migrantes caritas Christi (2004). Praha, 2006. Jedná se o poměrně rozsáhlý dokument (104 článků), který je doplněn o právně-pastorační pokyny.

45 Albert-Peter Rethmann upozorňuje na to, že v určité míře je o pozitivním hodnocení kulturní rozmanitosti řeč již ve společném dokumentu Papežské rady Cor unum a Papežské rady pro pastoraci migrantů a lidí na cestách z roku 1992 s názvem „Uprchlíci - výzva pro solidaritu“. Dokument mj. hovoří o tom, že integrace má být interpretována nikoli jako jednostranná asimilace, nýbrž jako oboustranný proces mezi majoritou a minoritou, a připouští pluralitu kulturního života, přičemž „chápe kulturu ne jako statickou, nýbrž jako dynamicky se vyvíjející jednotku.“ - RETHMANN, Albert-Peter. Kirchliche Stellungnahmen zur Asyl- und Migrationspolitik. In FURGER, Franz (ed.). Jahrbuch für christliche Sozialwissenschaften 35. Band (1994), Münster, 1994, s. 189-209, zde s. 208. Srov. rovněž JAN PAVEL II. Poselstvi ke svétovému dni uprchliků 2002, Praha, 2002. „Dnešní fenomén migrace můžeme tedy považovat za velmi důležité znamení doby, za výzvu, kterou máme objevovat a zhodnocovat pro budováni obnoveného lidstva a pro zvèstováni evangelia pokoje.“ (čl. 14) 
a mezikulturním dialogem jako zvláštní šanci k budování pokojnějšího soužití všech lidí. Cizinci v tomto ohledu představují rovněž „viditelné znamení a důležitou připomínku univerzalismu, který je konstitutivním prvkem katolické církve" (čl. 17).

$\mathrm{Z}$ uvedeného je patrné, že celocírkevní dokumenty, texty papežů a instrukce vatikánských dikasterií o migraci představují variabilní korpus textů a úvah, který nelze chápat jako uzavřený, neměnný, systematicky vypracovaný koncept „křestanského pojednání o migraci“. Texty se u vědomí svého žánru ve světle biblické a teologické tradice snaží patřičně reagovat na aktuální problémy a otázky spjaté s migrací a zabývají se tímto fenoménem nikoli pouze z pohledu abstraktně koncipovaných teologicko-etických úvah, nýbrž rovněž s ohledem na sociální skutečnost a praktické etické výzvy. ${ }^{48}$ Velmi napínavou otázkou, které bych se rád v následujících odstavcích stručně věnoval, pak zůstává, jaká odůvodnění stojí v pozadí těchto reflexí.

\section{Odůvodnění postojů k migraci v sociálním učení církve}

Postoje k migraci v sociálním učení katolické církve se opírají o dva principy. V rámci silového pole těchto dvou principů se utváří reflexe o eticky zodpovědném zacházení s migrací jako takovou. Tyto principy můžeme charakterizovat jako 1. princip světoobčanský či kosmopolitní a 2. princip politický. ${ }^{49} \mathrm{~V}$ reflexi migrace jde o harmonizaci napětí mezi světoobčanským principem, opírajícím se o jedinečnou lidskou důstojnost a univerzální lidská práva, na jedné straně a právem suverénních států na hraniční kontroly a regulaci migrace na straně druhé. 50

Oba principy budou ve vztahu k dané problematice stručně představeny. Následně budou ukázány etické podněty pro zacházení s migrací v rámci vybraného dokumentu místní církve, který se toto napětí mezi oběma principy pokouší tematizovat a prostřednictvím některých podnětů konkretizovat. Jeho jedinečnost spočívá nejen v pozoruhodné argumentaci a hloubce reflexe, nýbrž rovněž v tom, že se na něm podíleli společně biskupové zemí, mezi nimiž intenzivní migrace obyvatel dlouhodobě probíhá.

48 Srov. RETHMANN, Albert-Peter. Asyl und Migration, s. 270.

49 Srov. RAJENDRA, Tisha M. Migration in der katholischen Soziallehre, s. 248-256.

50 Srov. tamtéž, s. 248. 


\subsection{Světoobčanský princip}

Tento princip vychází ze základního principu sociálního učení církve - z principu personality. Každý člověk, bez ohledu na svou státní příslušnost, má jedinečnou, neodnímatelnou důstojnost a je nositelem lidských práv. Člověk jako osoba má být mírou utváření všech sociálních struktur, řádů, institucí a organizací. Úsilí o lidskou důstojnost a integrální rozvoj člověka, které se opírá o křestanské pojetí člověka, představuje stálý referenční bod reflexe o migraci. K úkolům křestanů a křestanských církví patří zasazovat se za důstojnost člověka a za stejná práva pro všechny lidi. Znamená to rovněž zasazovat se za boj proti jakékoli formě rasismu a xenofobie, což - jak upozorňuje Albert-Peter Rethmann - patří „k vůbec nejstarším prvkům křestanského sociálního učení". 51

Světoobčanský princip - jak naznačuje již samo spojení - zahrnuje biblické pojetí světa především jako totus orbis a zdůrazňuje jednotu lidské rodiny.52 Biblické texty a křestanská tradice nahlížejí svět primárně jako společenství všech lidí, kde oddělení mezi jednotlivými národy jsou sekundární a kde si jsou všichni lidé principiálně rovni. Jako primární je chápána příslušnost k lidskému pokolení, zatímco př́slušnost k určitému národu nebo rase je vnímána jako skutečnost sekundární. Chápání světa jako jednoho Božího stvoření implikuje, že „jednota světa má přednost před dělením na jednotlivé národní státy“. ${ }^{53}$ Právě toto východisko je v církevních dokumentech opakovaně zdůrazňováno. ${ }^{54}$

Korelativním principem k principu jednoho světa (totus orbis) pak je tradiční učení o univerzálním určeni statků. ${ }^{55}$ Princip univerzálního určení statků pramení ze skutečnosti, že „Bůh určil zemi a všechno, co je na ní, k užívání všem lidem a národům, takže stvořených statků se má dostat všem spravedlivou měrou“. ${ }^{6}$ Reflexe vychází z předpokladu,

51 RETHMANN, Albert-Peter. Kirchliche Stellungnahmen, s. 193. Rethmann poukazuje na to, že problémem rasismu se zabývá již encyklika Benedikta XIV. Immensa Pastorum z roku 1741.

52 K biblickému pojetí a této problematice srov. ŠTICA, Petr, Cizinec v tvých branách, s. 94-104.

53 RETHMANN, Albert-Peter. Žiješ mezi námi a jsi tu vítán. Katolický týdeník 4 (2005), s. 3.

54 Srov. např. PAPEŽSKÁ RADA PRO PASTORACI MIGRANTU゚ A LIDÍ NA CESTÁCH. Církev a rasismus. Za bratrskou společnost, Řím 1988. - Srov. RETHMANN, Albert-Peter. Kirchliche Stellungnahmen, s. 193.

55 Srov. RETHMANN, Albert-Peter. Asyl und Migration, s. 271.

56 Gaudium et spes, čl. 69. Srov. JAN PAVEL II. Sollicitudo rei socialis, čl. 42. 
že na počátku světa byly lidem všechny věci společné, proto si nikdo nemůže zcela přivlastnit půdu, teritorium a výlučný přístup k přítomným zdrojům. Univerzální určení statků implikuje jejich univerzální užívání. Takové univerzální užívání statků představuje podle Jana Pavla II. „první zásadu celého společensko-mravního řádu“.57

Poněvadž mají někteří lidé ztížený (a v důsledku nerovný) přístup k těmto statkům a zdrojům nezbytným pro materiální i nemateriální rozvíjení životních šancí, implikuje uvedená zásada solidární opci pro chudé. Teologicko-etická reflexe na tomto místě zdůrazňuje potřebu zmocňovat slabé k rozvinutí jejich životních šancí a pomáhat jim v zajištění sociálně-ekonomických dober nutných pro vydařený život. Dlužno podotknout, že argumentace církevních dokumentů na základě univerzálního určení dober se objevuje v souvislosti s migrací již v textech Pia XII. 58

Klíčovou roli zde hraje princip solidarity. Ten lze chápat jako z podstaty lidského bytí nutné sociální rozvinutí či sociální explikaci principu personality. ${ }^{59}$ Mají-li lidé realizovat svoje životní šance a rozvíjet své možnosti a práva, jsou nutně z povahy jejich bytí, které má sociální charakter, povoláni k interakci. To s sebou přináší vzájemnou odpovědnost. Světoobčanský princip tak především ukazuje, že je třeba s migranty zacházet solidárně, bez ohledu na jejich právní status nebo př́slušnost $\mathrm{k}$ danému státu. ${ }^{60} \mathrm{~S}$ migranty je třeba jednat jako s osobami, nositeli lidských práv. Solidarita je podle sociálního učení církve - jak podotýká Jan Pavel II. - uznáním naší vzájemné závislosti. ${ }^{61}$ Vědomí této vzájemné závislosti se má odrážet v regulaci migrace, která nemá být řízena pouze pragmatickými kritérii.

57 JAN PAVEL II. Laborem excercens, čl. 19.

58 Srov. PIUS XII. Svatodušní poselství u příležitosti 50. výročí encykliky Rerum novarum. AAS (1941), 247; TÝŽ, Exsul Nazarena.

59 Cílem solidarity je zaručit lidská práva pro všechny, a tak všem vytvořit rámec a umožnit rozvíjení jejich životních šancí. Solidaritu tak lze chápat jako povinnost odpovídající nároku kladenému lidskými právy. Srov. ANZENBACHER, Arno. Křestanská sociálni etika: úvod a principy. Brno: CDK, 2004, s. 198.

60 Srov. RAJENDRA, Tisha M. Migration in der katholischen Soziallehre, s. 249.

61 „Jde o propojenost, která je přijímána jako morální kategorie. Je-li za takovou uznávána, pak jí odpovídá - jako postoj mravní a společenský, jako ,ctnost‘ - solidarita. Není to tedy jen neurčitý soucit nebo povrchní dojetí nad zlem, týkajícím se mnoha blízkých a vzdálených osob. Naopak, je to pevná a trvalá odhodlanost usilovat o obecné blaho neboli dobro všech a jednoho každého, protože všichni jsme zodpovědní za všechny.“ - JAN PAVEL II. Sollicitudo rei socialis, čl. 38. 
Světoobčanský princip představuje bez pochyby základní východisko sociálně-etické reflexe o migraci. ${ }^{62}$ Někteří teologové 63 se vyjadřují v tom smyslu, že by ideál světového občanství, v němž je na migranty nahlíženo jako na „občany hypotetické světové republiky, která se až doposud konkretizuje v partikulárních státních formách,“64 měl zůstat důležitým „referenčním bodem“ reflexe otázky imigrační politiky v soudobém světě. $V$ církevních dokumentech lze však podobně jako v teologické debatě vypozorovat ještě další princip, u něhož je třeba se zastavit.

\subsection{Politický princip}

Politický princip spočívá na jedné straně v právu na migraci (jde o právo chápané zejména jako právo na emigraci a právo jednotlivých osob na usazení v jiném státě, pokud se jim v zemích původu nedostává lidských práv, možnosti rozvoje a důstojných životních podmínek) a na druhé straně v právu států přistěhování regulovat. Státy mají podle katolického sociálního učení povinnost přijímat migranty v nouzi a „zároveň právo kontrolovat hranice. Toto právo ale není absolutní،“65

Právo států na regulaci migrace jsou omezeny dvojím požadavkem - 1. povinností sloužit obecnému dobru, 2. povinností chránit lidská práva migrantů. ${ }^{66} \mathrm{O}$ druhém požadavku již byla řeč v předchozích odstavcích. Jedná se např. o nasazení v boji proti obchodu s lidmi, o ochranu iregulárních migrantů a jejich práv, o preferenci a kategorický požadavek přijetí politických uprchlíků, ale rovněž o boj proti příčinám migrace a uprchlictví. Požadavek sloužit obecnému dobru, který je v souvislosti s právem států na regulaci migrace zmiňován již v apoštolské konstituci Exsul Familia, ${ }^{67}$ je však třeba diferencovat.

62 Srov. TOMASI, Silvano M. Migration und Katholizismus im globalen Kontext, s. 527-528.

63 Srov. např. Walter LESCH, Walter. Migrationspolitik und Staatsbürgerschaftsregelungen: Aspekte einer Ethik der Integration. Ethica 1999, č. 3, s. 281-306, zde s. 295.

64 LESCH, Walter. Paradigmenwechsel in der Einwanderungspolitik. Vom Streit der Kulturen zum Streit um die Verteilungsgerechtigkeit. In Orientierung 2002, č. 2, s. 16-20, zde s. 19.

65 RAJENDRA, Tisha M. Migration in der katholischen Soziallehre, s. 252.

66 Srov. tamtéž, s. 252-254.

67 „Stvořitel veškerenstva stvořil všechny věci primárně pro dobro všech. Protože země nabízí možnost uživit velké množství lidí, nemůže být suverenita států, jakkoli musí být také velmi respektována, přehnaně uplatňována, aby potřebným a slušným lidem z jiných zemí, at' už z přiměřených nebo neopodstatněných důvodů, nebyl umožňován vstup do země, za předpokladu, že tomu nebrání velmi pečlivě zvážené veřejné 
Obecné dobro (bonum commune) zaujímá v rámci křestanské sociální etiky ústřední postavení a spolu s principem solidarity představuje jedno se zásadních rozvinutí principu personality. Jedná se o implikaci plynoucí z náhledu na lidský život v jeho sociální dimenzi. Poněvadž nutnou dimenzí lidského života je dimenze sociální, musí lidé usilovat nejen o dobro osobní, nýbrž i o dobro obecné. Politické společenství coby instance prostředkující veřejná dobra, která si nemohou osoby či subsidiární společenství zajistit samy a která jsou nezbytná pro rozvoj jednotlivých osob, čerpají svou legitimitu právě v zaručování obecného dobra. ${ }^{6}$

Obecné dobro má však mnoho podob a okruhů působnosti. V samotném pojmu obecného dobra lze vnímat víceznačnost (obecné dobro lokální vedle obecného dobra globálního), která se jasně ukazuje právě v otázce regulace migrace. K tomu je třeba dodat, že obecnému dobru nesmí scházet proveditelnost $\mathrm{v}$ otázce zaručování lidsko-právních dober, která předpokládá prostředkování obecného dobra skrze subsidiární struktury, ani univerzální charakter.

V současném světě je - zřejmě jako nikdy předtím v dějinách - patrná provázanost jednotlivých států a regionů. S tím je rovněž patrná existence a propojenost různých obecných dober mezi sebou. Sociální učení církve uznává tuto provázanost globálního společenství lidí s partikulárním společenstvím, stejně jako vztah obracený a potvrzuje, že „dobro určitého národa je neoddélitelné od dobra celé lidské rodi$n y{ }^{6 "} .{ }^{69}$ Proto se ve vztahu k migraci interpretuje služba obecnému dobru ve smyslu lokálního dobra i dobra světového a ve smyslu podpory lidských práv všech lidí - občanů vlastního státu, ale i těch, kteří se v daném státě chtějí a mohou usadit. Požadavek úsilí o obecné dobro znamená jak úsilí o obecné dobro lokální, regionální či státní, tak úsilí o obecné dobro globální.

Toto napětí se snaží reflektovat jeden z nejpozoruhodnějších dokumentů místních církví k otázce migrace - obsáhlý společný pastorační list biskupů Mexika a Spojených států amerických, který byl publikován roku 2003, s názvem Strangers No Longer: Together of the Journey

dobro““ PIUS XII. Exsul familia (dokument není dělen na články). Citováno podle RAJENDRA, Tisha M. Migration in der katholischen Soziallehre, s. 252.

68 Gaudium et spes, čl. 74; srov. REMELE, Kurt. Das Wohl aller und eines jeden: Gemeinwohl und Individualwohl nach der katholischen Sozialethik. Ethica 2005, č. 2, s. $115-134$, zde s. 123.

69 Kompendium, čl. 434. 
of Hope. ${ }^{70}$ Uvedený pastorační dopis zmiňuje mj. pět základních principů pro migraci a imigrační politiku v pohledu katolické sociální nauky (čl. 33-39). Jsou jimi následující teze:

1. Lidé mají právo najít př́ležitosti pro rozvíjení vlastních životů ve své vlasti.

2. Lidé mají právo migrovat, aby uživili sami sebe a své rodiny.

3. Suverénní státy (nations) mají právo kontrolovat své hranice.

4. Uprchlíkům a žadatelům o azyl má být poskytnuta ochrana.

5. Lidská důstojnost a lidská práva neregulárních migrantů (undocumented migrants) mají být zachovány.

Dokument uvádí, že „pokud lidé nemohou najít zaměstnání ve své vlasti pro uživení sebe a svých rodin, mají právo najít práci jinde, aby mohli přežít. Suverénní státy by měly tomuto právu vyjít vstříc“ (čl. 35). Vedle uznání práva na emigraci je poukázáno na to, že regulace migrace má být utvářena principem solidarity a preferenční opce pro chudé.

Tento požadavek je dále konkretizován: „Církev uznává právo suverénních států kontrolovat své území, ale odmítá takové kontroly, které by byly uplatňovány pouze za účelem zajištění nadbytečného bohatství. Ekonomicky silnější státy, které jsou schopny ochránit a uživit své rezidenty, mají silnější povinnost vycházet vstříc migračním tokům“ (čl. 36). Poslední věta představuje základní etický požadavek spjatý s regulací imigrace - přiměřenou míru otevřenosti a solidárního postoje ze strany přijímajících států, zvláště těch, které jsou ekonomicky silnější, vůči ekonomickým imigrantům (u politických uprchlíků se jedná o kategorický požadavek přijetí).

Uvedený církevní dokument poukazuje na provázanost obou principů - světoobčanského a lidsko-právního principu na jedné straně a politického principu na straně druhé: „Církev uznává právo suverénního státu kontrolovat své hranice za podpory obecného dobra. Uznává také právo lidských osob migrovat, aby mohli realizovat práva, daná od Boha. Tato učení se vzájemně doplňují. Zatímco suverénní stát může stanovit rozumné meze imigrace, společné dobro není zaručeno, jsou-li porušována základní lidská práva. Ve stávajících podmínkách ve světě, v němž je hojně rozšířena globální chudoba a pronásledování, je třeba vycházet z toho, že lidé musí migrovat, aby uživili a ochránili

70 Strangers No Longer: Together of the Journey of Hope. A Pastoral Letter Concerning Migration from the Catholic Bishops of Mexico and the United States. Dostupné na: http://www.usccb.org/mrs/stranger.shtml [1. 9. 2011]. K následujícímu srov. rovněž ŠTICA, Petr. Migrace a státní suverenita, s. 269-271. 
sami sebe, a že státy, které jsou schopné je přijmout, je mají přijímat, pokud je to možné.“ (čl. 39)

Poukazuje tak nejen na to, které hodnoty mají utvářet imigrační politiku, nýbrž rovněž na to, že politicky-praktický kontext, v němž se lidská práva zaručují, a lidská práva coby normativní východisko se vzájemně doplňují. Následuje řada konkrétních podnětů pro pastorační působení a proměnu farností místních církvích v místa, v nichž vládne duch obrácení, pohostinnosti, společenství, solidarity a úsilí o spravedlnost, nýbrž i pro veřejnou politiku, a to jak v zemích původu, tak v zemích imigračních.

Úkolem křestanů tak zůstává nejen poukazovat na ideály a principy, které by se měly promítnout do imigrační politiky, nýbrž rovněž usilovat o prosazení těchto ideálů v partikulárním a globálním kontextu. Bernhard Eder tuto skutečnost shrnuje následujícími slovy: Sociální učení církve stojí v konkrétním politicko-praktickém kontextu a vnáší do něj kosmopolitní orientaci. Zároveň ale uznává, že pokud by ideje spojené s touto orientací nebyly reflektovány a realizovány v partikulárních společenstvích, které zahrnují určitou míru výlučnosti, zůstaly by pouze abstraktním pojmem. Důsledně nicméně bez přestání poukazuje právě na tyto hodnoty, o něž se místní společenství opírají, i na to, že každý partikulární stát je zavázán univerzálními principy, které zahrnují i úsilí o dobro mimo hranice partikulárního společenství. Jinými slovy zdůrazňuje, že migrační politika nesmí ztratit globálněetickou a lidsko-právní orientaci. ${ }^{71}$ Světoobčanský a politický princip, které je možné v církevních dokumentech týkajících se migraci vypozorovat, lze tak interpretovat jako komplementární principy, kdy jeden vůči druhému plní „úlohu vzájemného strážce“.

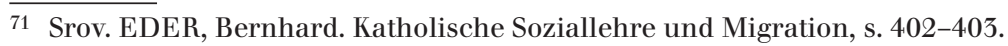




\section{ABSTRACT \\ PETR ŠTICA \\ Migration in Catholic social teaching}

The aim of the article is to present fundamental developments in the topic of "migration" in Catholic social teaching. The article is focused on the development thematic accents as well as argumentation within key texts and is limited to the main texts of magisterial teaching (council documents, papal encyclicals and writings, etc.). Afterwards, the rationalization for and the background (main principles) to these reflections are briefly introduced.

\section{Key words}

migration, Catholic social teaching, history of social teaching, ethics 